
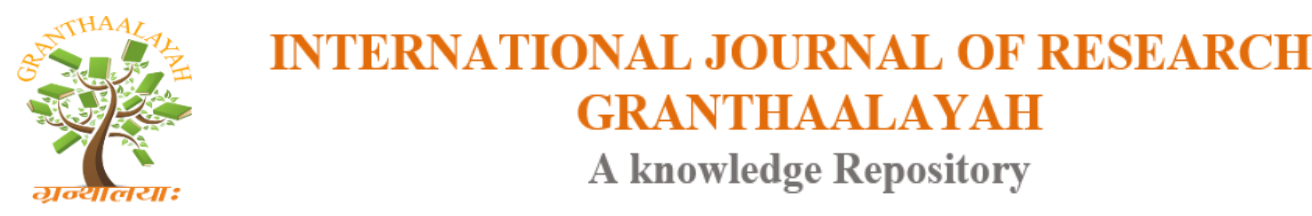

Management

\title{
UNIVERSAL NATIONAL IDENTITY CARD (UNID) AND ITS MODERNIZATION ON THE CONTEXT OF DIGITAL BANGLADESH
}

\author{
Md.Mahbobor Rahaman*1, Md.Foysal Hasan², Fatema Jannat Juhi ${ }^{3}$, Juhora Jamin Juha ${ }^{4}$ \\ ${ }^{* 1}$ Lecturer, Department of Business Administration, Leading University, Sylhet, Bangladesh \\ ${ }^{2}$ Lecturer, Bangladesh Institute of Bank Management (BIBM), Dhaka, Bangladesh \\ ${ }^{3}$ Independent Researcher, MA in Philosophy from University of Dhaka, Dhaka, Bangladesh \\ ${ }^{4}$ Lecturer, Department of Business Administration, Leading University, Sylhet, Bangladesh
}

\begin{abstract}
Bangladesh is one of the rapidly developing countries not only the south Asian region but also around the world. Each and every day Bangladesh has been introducing new and impressing ideas in compare with the developed countries. The government of Bangladesh has recently introduced new vision of digitalization each and every parts of this country. In this paper an important issue, national Identity (NID) card and its modernization, was discussed with some tremendous thinking on the context of digital Bangladesh. The paper was divided in to two parts one is current or existing National ID card systems and the second part was making a universal and modernization of this NID on the context of digital Bangladesh. In this paper there was a suggestion for making a Universal NID (UNID) card for Bangladeshi nations. Each and every task can be done by this Universal NID (UNID) card within Bangladesh and government maintain a data center or database office for collecting all the data around country. Finally, this paper suggests some recommendations for making a successful Universal NID (UNID) card on the context of digital Bangladesh.
\end{abstract}

Keywords: Digitalization; National Identity Card; Universal; Digital Bangladesh; Modernization.

Cite This Article: Md.Mahbobor Rahaman, Md.Foysal Hasan, Fatema Jannat Juhi, Juhora Jamin Juha. (2018). "UNIVERSAL NATIONAL IDENTITY CARD (UNID) AND ITS MODERNIZATION ON THE CONTEXT OF DIGITAL BANGLADESH." International Journal of Research - Granthaalayah, 6(5), 413-430. 10.29121/granthaalayah.v6.i5.2018.1469.

\section{Introduction}

Digital Bangladesh consists of two main parts one is digital and another is Bangladesh. All the sectors will be digitalized and the benefits of Information Communication Technology (ICT) will go for the prosperity of the society(Digital Bangladesh, 2013).From the concept of digital Bangladesh, it will take stepping us an Information Communication Technology (ICT) driven knowledge based society where all information will be readily available on-line or internet and where all possible tasks of the government organizations, semi-government organizations, 
autonomous organizations and also non-government organizations (NGOs) will be processed by the help of technology. The government of Bangladesh is highly engaged with the philosophy of digitalization process (Salim, 2017). To make any digital initiative ICT is the backbone of this initiative. Each and every sectors of the country can make digitalizing with the help of ICT. It grape the grandiose areas of information ensuring connectivity through the technology of information, technology of communication, computer technology and the most important technology of telecommunication(Digital world 2017, 2017). The dream of a Digital Bangladesh would be possible if the universal NID card was properly implemented.

A report published in the Dhaka tribune, (Bangladesh, 2016) regarding the smart digital NID in which twenty security characteristics have been added to three tiers more over international standard and reliability of the smart NID cards have been ensured in here. Five-tier 100 percent polycarbonate elements have been used and it would sustain at least 10 years in smart ID. The personal information has been showed through laser engraving which is not possible in general printers and transparent hologram has been incorporated in it for more security purpose(National , 2016). The information of a person exist in the added chip ,biometrics and photos have been preserved in electronic way(Bangladesh National, 2016). Moreover running of different apps would be possible through this chip, 10-digit random generated unique number has been introduced and a chip which 2D barcode and machine readable zone (MRZ) has been kept for using information properly (Rahman Z. , 2016). The collected data has been developed as per the compliance of the International Civil Aviation Organization (ICAO) which is acceptable internationally.

Digital Bangladesh comprises ensuring people's democracy and human rights, transparency, accountability, establishing justice and ensuring delivery of government services to the citizens of Bangladesh through maximum use of technology, with the ultimate goal being the overall improvement of the daily lifestyle of general people in which includes all classes of people and does not discriminate people in terms of technology use(Vision 2012, 2015). The long term vision of digital Bangladesh will be the human resource development, people involvement, civil services and the use of information technology in all aspect of business(Betterthancash, 2015).From the beginning of the digital Bangladesh the steps was very slow in process. Some scope exists for employment and income generation sectors like outsourcing, online retail and offering different public-private hybrid services through Union Information Service Centers have been implemented, the economy at large has remained stagnant (PERSPECTIVE PLAN OF BANGLADESH 2010-2021, 2015). In reality no significant development has taken place until 2015 and progress was slow from the digital Bangladesh vision (Rokonuzzaman, 2016). As an example the government planned to run the offices including the ministries through digitalized systems but until January 2015, the public offices were still serving through the traditional filing systems in 2015.But the mobile based money transfer or electronic banking system was running in urban to rural areas with a significant way in this year.

The first step of the national identity card of Bangladesh was a laminated paper in which all information of a voter was included as a voter of the country. But this voter ID card was replaced by the national ID card and its services were extended by the various format. From the tertiary stage of the digital Bangladesh the national ID card was made for their citizen in each and every task as a citizen of Bangladesh. In this national ID, a citizen of Bangladesh can get his all 
government and nongovernment services from various organizations by giving the valid national ID number. Now this national ID card is able to being acceptable format of driver's license, passport, trade license, tax payment and banking services. I addition this national ID card is now turning as a digital ID card it has 32 types of unique information of each citizen those who bring this digital ID card. The security system of digital ID card was designed by the 25 security features to prevent falsification. The government of Bangladesh primarily introduced all government organizations web sites and online appearance. As a result the responsibility and duty of the government organization was known the general people of this country (Bhuiyan, 2011). In the beginning of digital Bangladesh vision the government makes a national data center for preserving the all information of their citizens.

Bangladesh already has started the digital services all around the country. Some of the most common examples of this type of service are application for admission in various public institutions and universities, publication of JSC, JDC, SSC, HSC results on online, e-registration for jobs abroad, e-registration of pilgrimage, online official forms, e-tax returns, e-tendering and many more. Moreover e-banking systems have been speeding up the financial activities, apps for complaints to police stations, e-bill payments for utility services, high speed data communication, e-passport, telemedicine, videoconferencing for the treatment of diseases and administrative activities. To get these services in a high speed with high efficiency a universal national ID card is necessary for this reason government take some initiative to make a universal digital national ID.

\section{Literature Review}

From the definition of a2i, Digital Bangladesh implies the broad use of computers, and embodies the modern philosophy of effective and useful use of technology in terms of implementing the promises in education, health, job placement and poverty reduction that means in all aspect the way life will be digitalized(Rahman L. , 2015). Every government of the world wanted to develop an identity card for their citizen's identifications. Generally, a national identity card is a portable document, typically a plasticized card with digitally embedded information, that someone is required or encouraged to carry as a means of confirming their identity and nationality. Around the world, many types of Identity (ID) cards are using, in one form or another in numerous countries. The process, types, functions, integrity were varied from country to country. The successful e-government will be available when all aspect, such as government, nongovernment, for profit, not for profit,small, medium and large organizations, will be in one shade(Palvia \& Sharma, 2016). Social capital is an important factor in increasing citizen's trust for making properly equipped digital nations(ALONSO, 2009).E-participation dimension should be adapted by the government for making the universal NID(UNID) with three stages(e-enabling,eengaging,e-empowering)step by step(Islam, 2008). The best utilization of UNID will be available when the supporting part of e- government,e-commerce,e-education,e-legislation,e-learning,ehealth will work together(Nkwe, 2012).

There should be follow a benchmark for making UNID in Bangladesh. It can follow the country like United States, Canada, New Zealand, Australia, Ireland, the Nordic countries and Sweden which were using the national identity card with a high security and fully digitalized format(Bovaird \& Löffler , 2002). Some other countries such as Germany, France, Belgium, 
Greece, Luxembourg, Portugal and Spain were also using the national identity card or as any other name. It's also obligatory to get each citizen a unique national identity card for their(Macintosh \& Whyte, 2006). The misuse of national identity card is a great fear among the nations, even in U.S or Canada. Government can monitor maximum activities in various way of digitalization (Ndou, 2004). But the real fact is was that national identity card was not misused by the political government. This national identity card may not totally prevent the terrorism but it can minimize it mostly(M \& S, 2010). India has introduced the Multipurpose National Identity Card (MNIC) which would give the citizen a 16-digit ID number and tamper-proof customized cover that is both waterproof and able to sustain extreme temperatures, microprocessor $16 \mathrm{~KB}$ chip, readable on offline and also readable by reader(Rao, 2004).

India has been planning to make the digital India but it is still very difficult to implementing this process, most of the political leaders were not aware about this digitalization process(Heeks, 2006). The political pressure against this digitalization has interrupted the digital India(Chul \& Eom, 2009). So it is the most common factor in south Asian nation and also in developing or underdeveloped countries in the world. In Bangladesh the same problems may also arise in the near future(Tania, Devindra, \& John, 2007). The digitalization of national ID card in Sri Lanka was started in short range but now this process is a successful established process in their government(Simon, David, \& Fabrizio, 2007). The government of Sri Lanka first introduced eight digits national ID card.By the digitalization and modernization process of Sri Lankan government the national ID card was digitalized and upgraded by the 12 digits national ID card(Mona, Samuel, \& Mats, 2010). The first four digits was for the birth year,the second three digits for number of days in the year of person birth,the next four digits for a serial number and the last one digit for check list. In some special ID there was an additional digit which was a special letter such as V. Sri Lanka was divided into 9 provinces for the arranging their national ID number(Dong \& Tae, 2008).

Another south Asian country namely Pakistan also introduced national ID card for their citizen living in home and abroad(Ailsa \& Liz, 2008). The government of Pakistan introduced their national ID into two categories one is Computerized National Identity Card(CNIC) which was for the citizen identity and another is Smart National Identity Card(SNIC) which was for the national election(Macintosh P. A., 2004). The features of SNIC of Pakistan was name of the citizen, father's name, gender, country stray, identity number, date of birth, photo, issue and expiry date, signature, OR code, card serial number, present and permanent address etc. The government of Pakistan allows their citizen to use CNIC and SNIC for taking their citizen services. The verification systems of national ID card in Pakistan was so simple to just send a SMS from the citizen of Pakistan mobile(Learninall, 2016).

The government of India has been expressing their motives to make a digital nation and fulfill the dream of digital India(Haricharan \& Ponnurangam, 2010).India introduced the nine pillars of making the digital India(Digital India/Pillars, 2017).In the digital infrastructure, it will focus on providing high speed secure Internet connection(Digital India, 2017). The governance and services on demand will stress on integrating services across departments and jurisdictions and making services available in real time for both online and cellular technology (Gupta, 2017). The empowerment of citizens will pay emphasis on universal digital literacy and availability of digital resources/services in Indian and also a world standard language(Digital India Progress, 2017).The 
best example of digital ID and digital nation was Maldives(ROSE, 2005). The government of Maldives introduced a single digital biometric ID card that combined the functions of passport, national ID, driver's license, health and insurance card, payment card which was accepted all over the world. The citizen of Maldives can use their digital biometric ID card for all purpose. They can use it as a bank debit or credit card all around the world (Sujana \& Ray, 2013).

\section{Materials and Methods}

This research was a conceptual research in its nature. The researcher takes an existing concept and then reinterprets this concept with some modifications.

\section{Research Methodology}

In this research the researcher takes an existing data from the digital Bangladesh. The data collection process was taken from the secondary sources from the various web sites, journals, online articles, books, various projects etc. Then this idea was breaking down into various parts to modify with updated data. The research was divided into three major parts. The first part of this research has shown the present status of national identity (NID) card of Bangladesh. The second part of this research also has analyzed the digital NID card of Bangladesh. And the final part of this research modified and modernized the NID as a digital format.

\section{Objectives of the Study}

The core objective of this study was to make a universal national identity card for Bangladeshi citizens in Bangladesh. Other objectives are-

1) To identify the current status of NID card in Bangladesh.

2) To give a guide lines for making a universal NID (UNID) card.

3) To develop or modernize the existing NID (UNID) card on the context of digital Bangladesh.

\section{Making Universal NID Card (UNID)}

The current National Identity Card (NID) in Bangladesh is consisting of 17 digits in which contain the date of birth and a number for each citizen. In this research, the researcher introduced a unique NID card for Bangladeshi nations in where there was a date of birth, a code for division (the highest tier of local government), a code for district (the second highest tier of local government), a code for upazila or thana(the third highest tier of local government), a code for citizen identity(ID) and a code for marital status. Primarily it was a laminated National Identity Card then it was modified as a plastic ID card with some built in memory. But till now most of the citizen dot get this plastic ID card. In the current National ID there was a photo, permanent address, date of birth, citizen name with their father and mother's name, bar cod and ID number. The first and foremost task was as same as the current NID. In the current NID the first four digits was assigned for the date of birth of each citizen in Bangladesh. In universal NID card also the four digits will be assigned for the date of birth of each citizen of Bangladesh. That means if any citizen birth 1950 then his/her universal NID card number will start with this date of birth. 


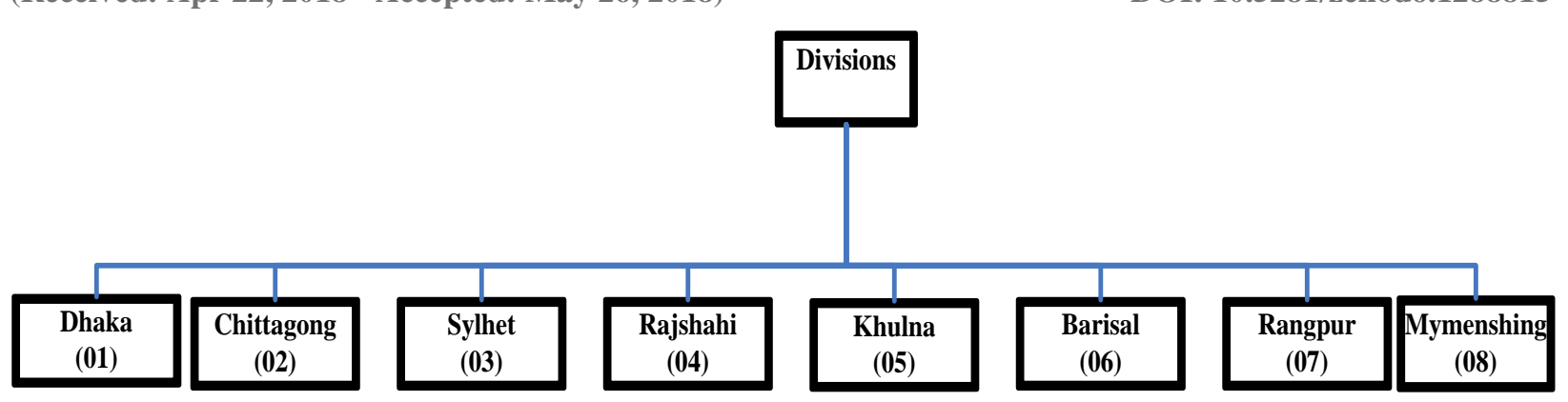

Figure 1: Division wise code allocation

The second task will be divided all the divisions into 8 parts. Each division will be assigned a unique number such as Dhaka will take 01, Chittagong will take 02, Sylhet will take 03, Rajshahi will take 04, Khulna will take 05, Barisal will take 06, Rangpur will take 07 and Mymenshing will take 08. That means in this format the Bangladesh can be divided in to 99 divisions. If in future there will be required the more divisions, these systems can take 99 divisions. In the figure 1 it was shown and it will be unique number for each citizen of Bangladesh.

In this stage each and every citizen will get their date of birth and division of birth code. That means in this stage the citizen will get 6 digits NID number. First 4 digits for the date of birth and second 4 digits for the divisions of his/her own. For example, a citizen was birth in 1950 and in the Dhaka division then his /her NID will be 199001. This unique NID will be assigned when the child was born.

\subsection{Dhaka Division}

This is the third sage of making universal NID for each citizen of Bangladesh. In this stage all the districts of every division will be assigned. For example, in Dhaka there are thirteen districts. Each district will be assigned a unique number.

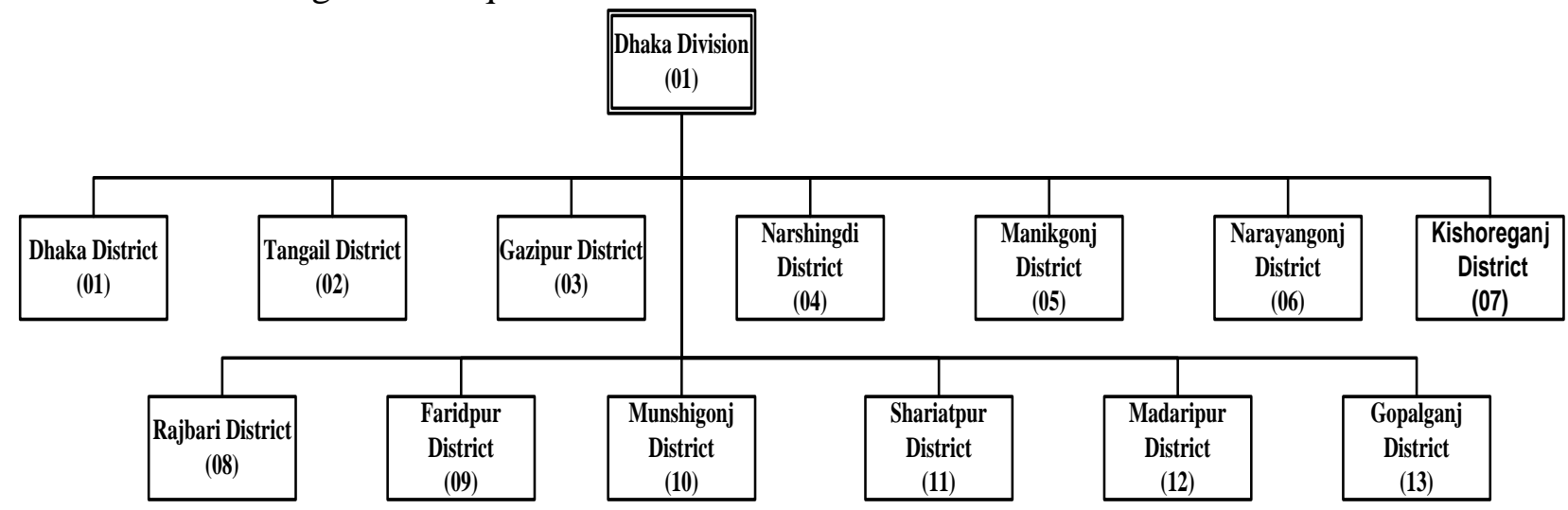

Figure 2: District wise code allocation from Dhaka Division

For example, the Tangail district from the Dhaka division and it will get a code like as for Dhaka division it will take 01, for Tangail district it will take 02 and the final code will be 0102.That means this number is for Tangail district from Dhaka divisions. As the same way it was shown in the figure 2 of the above presented. Each district there will be a unique code such Dhaka district 
from Dhaka division it will 0101, Tangail district from Dhaka division it will 0102, Gazipur district from Dhaka division it will 0103,Narshingdi district from Dhaka division it will 0104,Manikgonj district from Dhaka division it will 0105,Narayangonj district from Dhaka division it will 0106, Kishoreganj district from Dhaka division it will 0107,Rajbari district from Dhaka division it will 0108,Faridpur district from Dhaka division it will 0109,Munshigonj district from Dhaka division it will 0110,Shariatpur district from Dhaka division it will 0111,Madaripur district from Dhaka division it will 0112,Gopalganj district from Dhaka division it will 0113. For example, a citizen was birth in the year of 1960 in Dhaka division at Tangail district then his/her unique NID number will be in this stage 19600102 .

\subsection{Chittagong Division}

As the same way of Dhaka division the Chittagong division also assigned the separate number for making the UNID card. In this stage all the districts of Chittagong division will be assigned a unique number. For example, in Chittagong there are eleven districts. Each district will be assigned a unique number in such way.

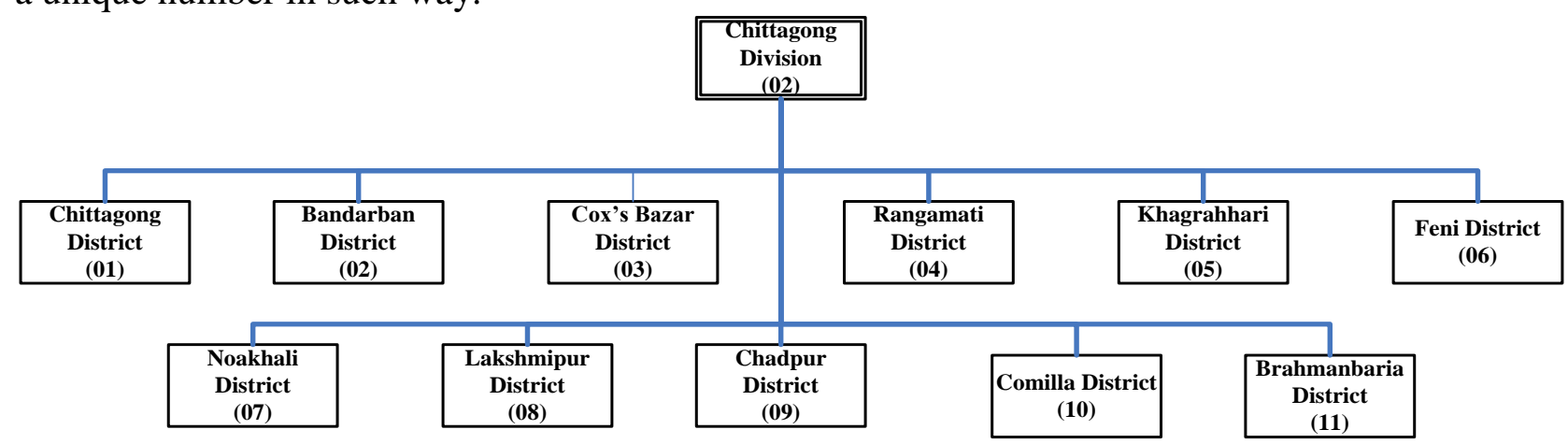

Figure 3: District wise code allocation from Chittagong Division

In this stage all the districts of Chittagong division will be assigned a unique number. For example, in Chittagong there are eleven districts. Each district will be assigned a unique number. For example, the Cox's Bazar district from the Chittagong division and it will get a code like as for Chittagong division it will take 02, for Cos's Bazar district it will take 03 and the final code will be 0203 and it will show on the table 3, that means this number is for Cox's Bazar district from Chittagong divisions. As the same way it was shown in the figure 2 of the above presented. Each district there will be a unique code such Chittagong district from Chittagong division it will 0201, Bandarban district from Chittagong division it will 0202, Cox's Bazar district from Chittagong division it will 0203, Rangamati district from Chittagong division it will 0204, Khagrachhari district from Chittagong division it will 0205, Feni district from Chittagong division it will 0206, Noakhali district from Chittagong division it will 0207, Laksmipur district from Chittagong division it will 0208, Chadpur district from Chittagong division it will 0209, Comilla district from Chittagong division it will 0210, Brahmanbaria district from Chittagong division it will 0210.For example, a citizen was birth in the year of 1960 in Chittagongdivision at Comilla district then his/her unique NID number will be in this stage 19600210. 


\subsection{Sylhet Division}

In this stage all the districts of Sylhet division will be assigned a unique number which was shown in the figure 4. For example, in Sylhet there are four districts. Each district will be assigned a unique number. For example the Moulavibazar district from the Sylhet division and it will get a code like as for Sylhet division it will take 03, for Moulavibazar district it will take 04 and the final code will be 0304 and it was shown on the table 4 .

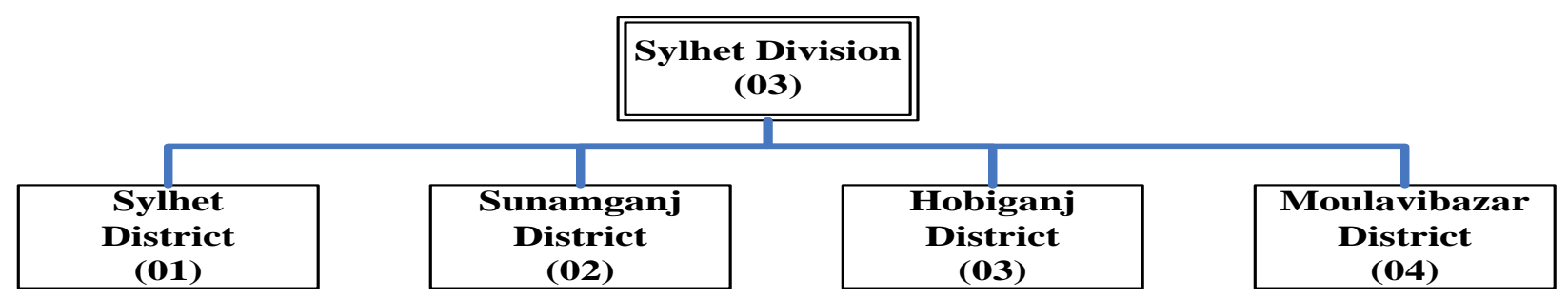

Figure 4: District wise code allocation from Sylhet Division

That means this number is for Moulavibazar district from Sylhet divisions. As the same way it was shown in the figure 4 of the above presented. Each district there will be a unique code such Sylhet district from Sylhet division it will be 0301, Sunamganj district from Sylhet division it will be 0302, Hobiganj district from Sylhet division it will be 0303, Moulavibazar district from Sylhet division it will 0304.For example, a citizen was birth in the year of 1960 in Sylhet division at Hobiganj district then his/her unique NID number will be in this stage 19600303.

\subsection{Rajshahi Division}

It was shown in the figure 4 in this stage all the districts of Rajshahi division will be assigned a unique number. In Rajshahi there are eight districts. Each district will be assigned a unique number. For example, the Naogaon district from the Rajshahi division and it will get a code like as for Rajshahi division it will take 04, for Naogaon district it will take 02 and the final code will be 0402 and it was shown on the table 5. That means this number is for Naogaon district from Rajshahi divisions. As the same way it was shown in the figure 5.

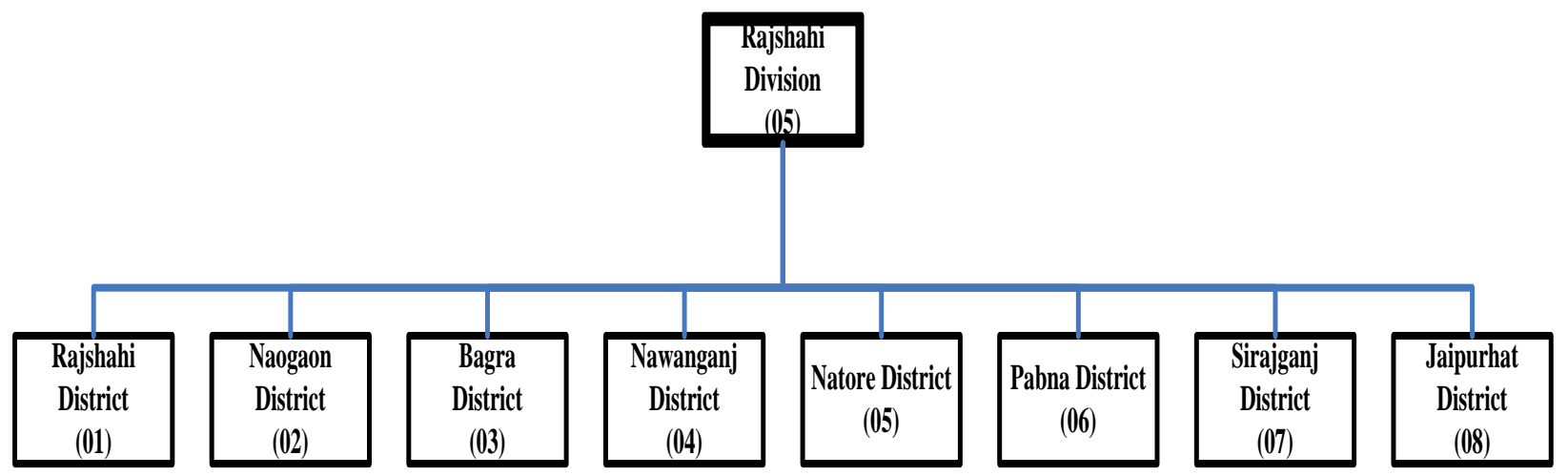

Figure 5: District wise code allocation from Rajshahi Division

Each district there will be a unique code such Rajshahi district from Rajshahi division it will be0401, Naogaon district from Rajshahi division it will be 0402, Bagra district from Rajshahi 
division it will be 0403, district from Rajshahi division it will be 0401. For example, a citizen was born in the year of 1960 in Rajshahi division at Noagaon district then his/her unique NID number will be in this stage 19600402 .

\subsection{Khulna Division}

It was shown in the figure 6 in this stage all the districts of Khulna division will be assigned a unique number.

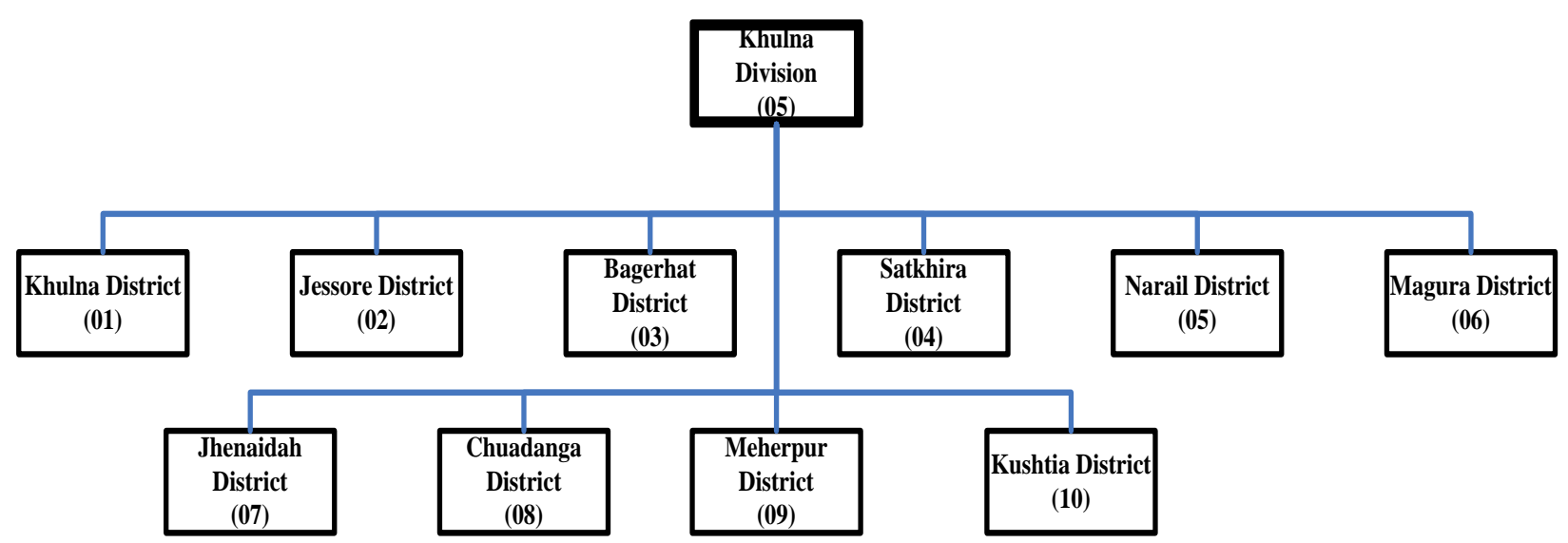

Figure 6: District wise code allocation from Khulna Division

For example, in Khulna there are ten districts. Each district will be assigned a unique number. For example, the Jessore district from the Khulna division and it will get a code like as for Khulna division it will take 05, for Jessore district it will take 02 and the final code will be 0502 and it was shown on the table 6. That means this number is for Jessore district from Khulna divisions. As the same way it was shown in the figure 6 . Each district there will be a unique code such Khulna district from Khulna division it will 0501, Jessore district from Khulna division it will 0502, Bagerhat district from Khulna division it will 0503, Satkhira district from Khulna division it will 0504, Narail district from Khulna division it will 0505, Magura district from Khulna division it will 0506,Jhenaidah district from Khulna division it will 0507, Chuadanga district from Khulna division it will 0508, Meherpur district from Khulna division it will 0509, Kushtia district from Khulna division it will 0510.For example, a citizen who was born in the year of 1960 in Khulna division at Jessore district then his/her unique NID number will be in this stage 19600502.

\subsection{Barisal Division}

It was shown in the figure 7 , in this stage all the districts of Barisal division will be assigned a unique number. For example in Barisal there are six districts. Each district will be assigned a unique number. For example, the Bhola district from the Barisal division and it will get a code like as for Barisal division it will take 06, for Bhola district it will take 02 and the final code will be 0602 and it was shown on the table 7. That means this number is for Bhola district from Barisal divisions. 


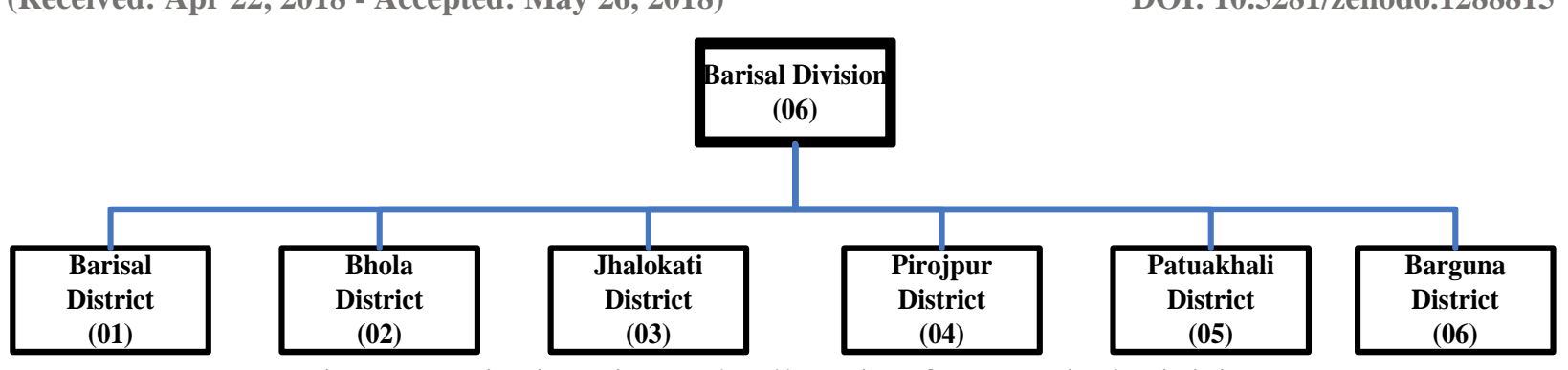

Figure 7: District wise code allocation from Barisal Division

As the same way it was shown in the figure 7. Each district there will be a unique code such Barisal district from Barisal division it will be 0601, Bhola district from Barisal division it will be 0602, Jhalokati district from Barisal division it will be 0603, Pirojpur district from Barisal division it will be 0604, Patuakhali district from Barisal division it will be 0605, Barguna district from Barisal division it will be 0606.For example, a citizen who was born in the year of 1960 in Barisal division at Barguna district then his/her unique NID number will be in this stage 19600606.

\subsection{Rangpur Division}

It was shown in the figure 8, in this stage all the districts of Rangpur division will be assigned a unique number. For example, in Rangpur there are eight districts. Each district will be assigned a unique number.

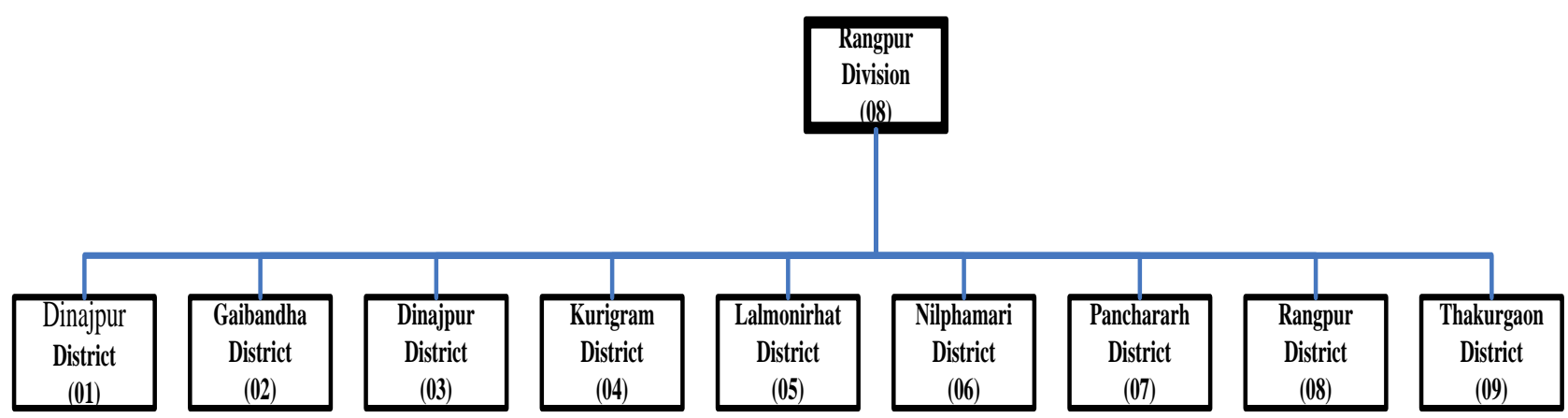

Figure 8: District wise code allocation from Rangpur Division

For example, the Lalmonirhat district from the Rangpur division and it will get a code like as for Rangpur division it will take 07, for Lalmonirhat district it will take 04 and the final code will be 0704 and it was shown on the table 8. That means this number is for Lalmonirhat district from Rangpur divisions. As the same way it was shown in the figure 8 . Each district there will be a unique code such Dinajpur district from Rangpur division it will be 0701, Gaibandha district from Rangpur division it will be 0702, Kurigram district from Rangpur division it will be 0703, Lalmonirhat district from Rangpur division it will be 0704, Nilphamari district from Rangpur division it will be 0705, Panchagarh district from Rangpur division it will be 0706, Rangpur district from Rangpur division it will be 0707, Thakurgaon district from Rangpur division it will be 0708.For example, a citizen who was born in the year of 1960 in Rangpur division at Kurigram district then his/her unique NID number will be in this stage 19600703. 


\subsection{Mymensingh Division}

It was shown in the figure 9, in this stage all the districts of Mymensingh division will be assigned a unique number. For example, in Mymensingh there are five districts. Each district will be assigned a unique number. For example, the Kishoregonj district from the Mymensingh division and it will get a code like as for Mymensingh division it will take 08, for Kishoreganj district it will take 02 and the final code will be 0802 and it was shown on the table 9 .

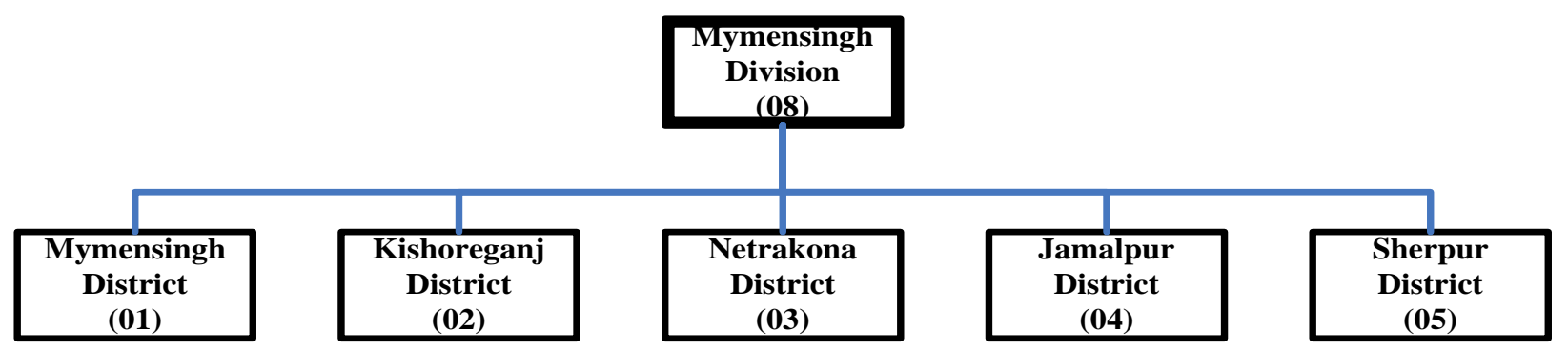

Figure 9: District wise code allocation from Mymensingh Division

That means this number is for Kishoreganj district from Mymensingh divisions. As the same way it was shown in the figure 9. Each district there will be a unique code such Mymensingh district from Mymensingh division it will be 0801, Kishoreganj district from Mymensingh division it will be 0802, Netrakona district from Mymensingh division it will be 0803, Jamalpur district from Mymensingh division it will be 0804, Sherpur district from Mymensingh division it will be 0805.For example, a citizen who was born in the year of 1960 in Mymensingh division at Jamalpur district then his/her unique NID number will be in this stage 19600804.

\subsection{Example of Dhaka Division For UNID}

This is the fourth sage of making universal NID for each citizen of Bangladesh. In this stage all the thanas or upazilas of every district from every division will be assigned a unique Identity number. For example, in Dhaka division there are thirteen districts and 46 upazilas/thanas. Each upazilas/thanas will be assigned a unique number. For example, the Badda thana of Dhaka district from the Dhaka division and it will get a code like as for Dhaka division it will take 01, for Dhaka district it will take 02, for Badda upazilas/thanas it will take 07 and the final code will be 010107.That means this number is assigned for Badda upazilas/thanas of Dhaka district from Dhaka divisions.

As the same way it was shown in the figure 10. Each upazilas/thanas of every district from each division there will get a unique number such Dhamrai upazilas/thanas of Dhaka district from Dhaka division it will be as like as 010101, Dohar upazilas/thanas of Dhaka district from Dhaka division it will be as like as 010102.Keraniganj upazilas/thanas of Dhaka district from Dhaka division it will be as like as 010103.Nawabganj upazilas/thanas of Dhaka district from Dhaka division it will be as like as 010104. Savar upazilas/thanas of Dhaka district from Dhaka division it will be as like as 010105. Adabor upazilas/thanas of Dhaka district from Dhaka division it will be as like as 010106. Badda upazilas/thanas of Dhaka district from Dhaka division it will be as like as 010107. Biman Bandar upazilas/thanas of Dhaka district from Dhaka division it will be as like as 010108. Bangshal upazilas/thanas of Dhaka district from Dhaka division it will be as like 
as 010109. Cantonment upazilas/thanas of Dhaka district from Dhaka division it will be as like as 010110.Chawkbazar Model upazilas/thanas of Dhaka district from Dhaka division it will be as like as 010111.Dakshinkhan upazilas/thanas of Dhaka district from Dhaka division it will be as like as 010112.Darus Salam upazilas/thanas of Dhaka district from Dhaka division it will be as like as 010113.Dhanmondi upazilas/thanas of Dhaka district from Dhaka division it will be as like as 010114. Demra upazilas/thanas of Dhaka district from Dhaka division it will be as like as 010115.Kotwali upazilas/thanas of Dhaka district from Dhaka division it will be as like as 010116.Gendaria upazilas/thanas of Dhaka district from Dhaka division it will be as like as 010117.Gulshan upazilas/thanas of Dhaka district from Dhaka division it will be as like as 010118.Hazaribagh upazilas/thanas of Dhaka

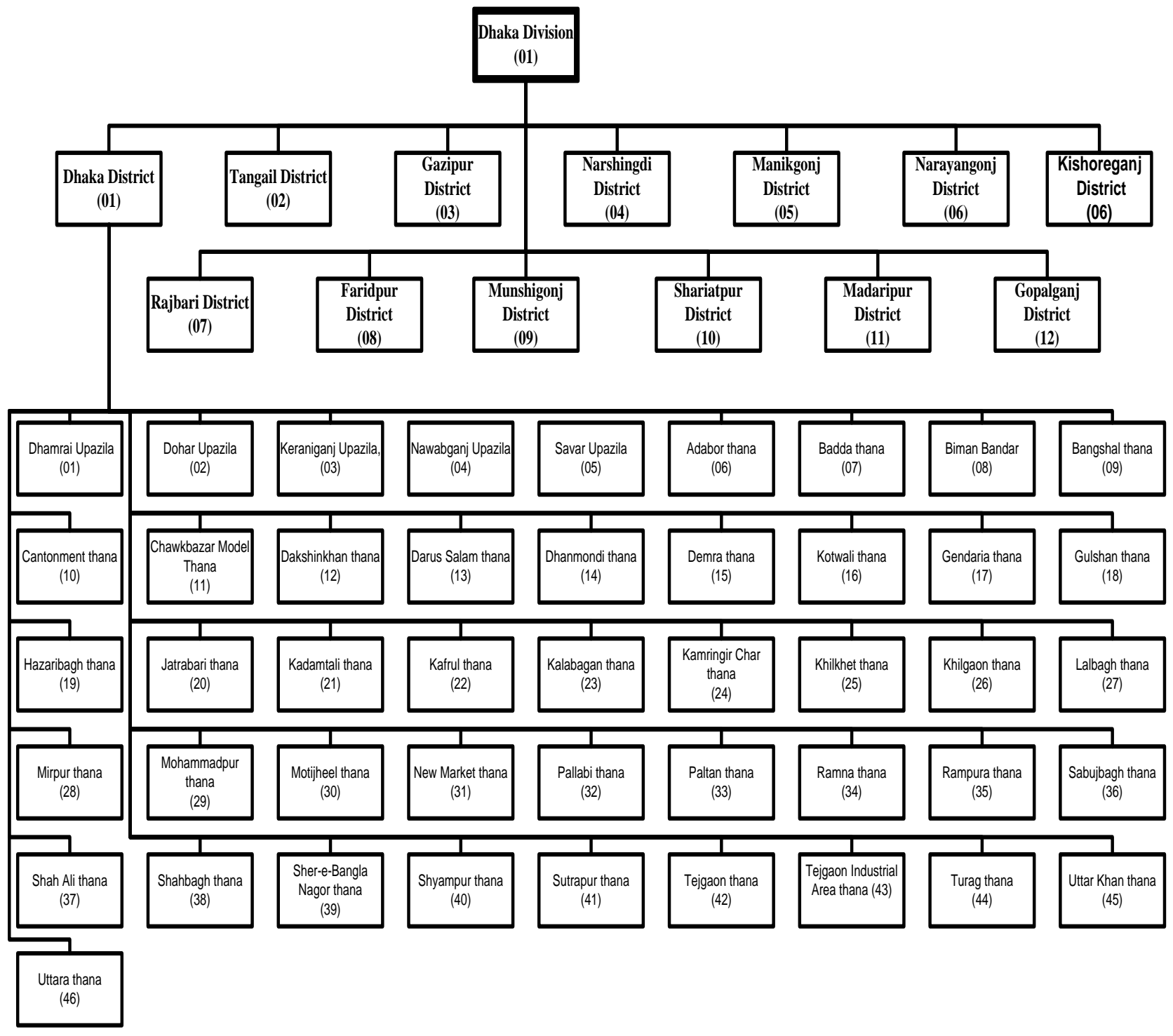

Figure 10: District wise code allocation from Dhaka Division

district from Dhaka division it will be as like as 010119.Jatrabari upazilas/thanas of Dhaka district from Dhaka division it will be as like as 010120. Kadamtali upazilas/thanas of Dhaka district from Dhaka division it will be as like as 010121.Kafrul upazilas/thanas of Dhaka district from Dhaka 
division it will be as like as 010122. Kalabagan upazilas/thanas of Dhaka district from Dhaka division it will be as like as 010123. Kamringir Char upazilas/thanas of Dhaka district from Dhaka division it will be as like as 010124 .

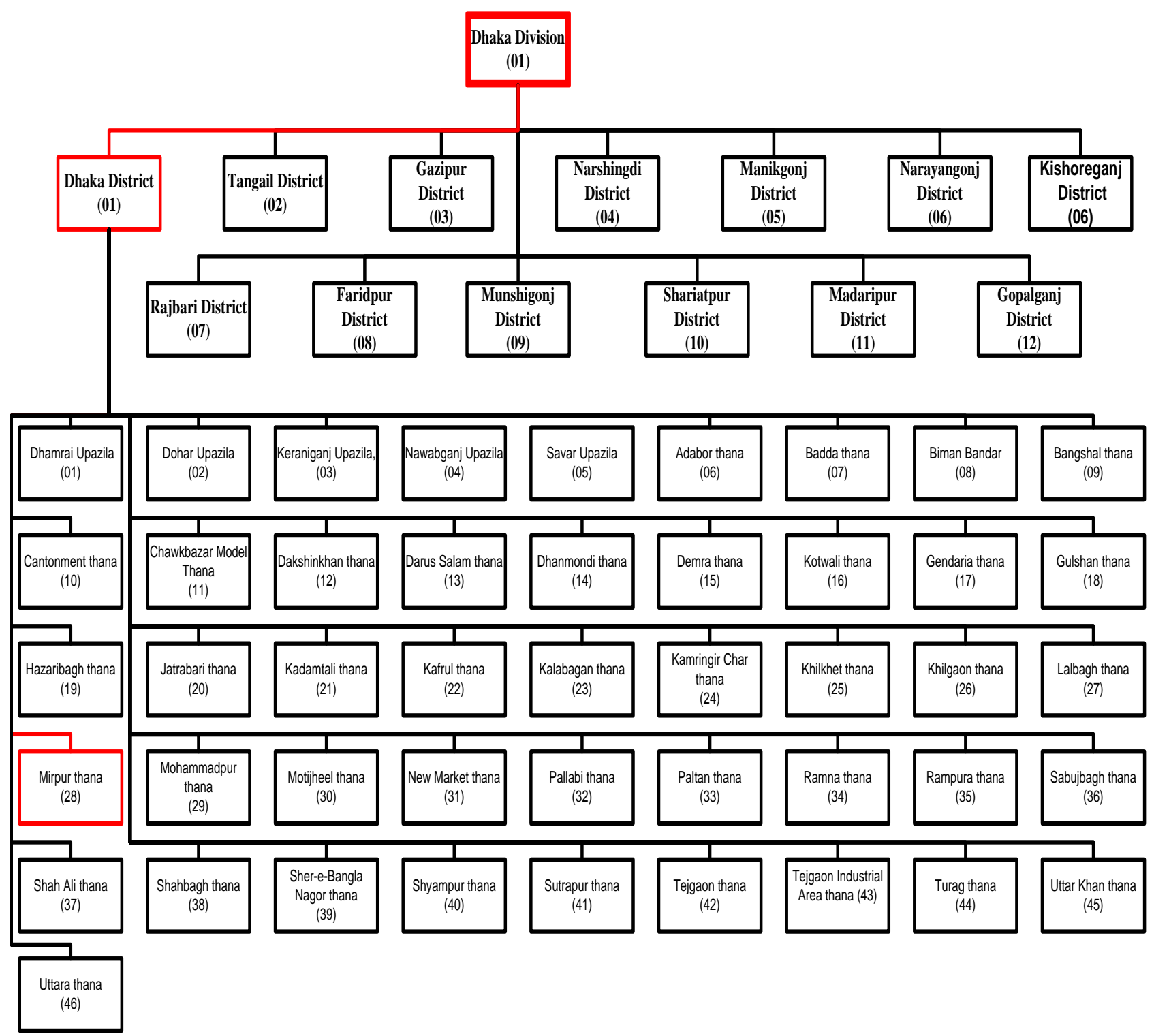

Figure 11: District wise code allocation from Dhaka Division, Dhaka district, Mirpur thana

Khilkhet upazilas/thanas of Dhaka district from Dhaka division it will be as like as 010125 . Khilgaon upazilas/thanas of Dhaka district from Dhaka division it will be as like as 010126. Lalbagh upazilas/thanas of Dhaka district from Dhaka division it will be as like as 010127.Mirpur upazilas/thanas of Dhaka district from Dhaka division it will be as like as 010128.Mohammadpur upazilas/thanas of Dhaka district from Dhaka division it will be as like as 010129.Motijheel upazilas/thanas of Dhaka district from Dhaka division it will be as like as 010130.New Market upazilas/thanas of Dhaka district from Dhaka division it will be as like as 010131.Pallabi upazilas/thanas of Dhaka district from Dhaka division it will be as like as 010132.Paltan upazilas/thanas of Dhaka district from Dhaka division it will be as like as 010133.Ramna 
upazilas/thanas of Dhaka district from Dhaka division it will be as like as 010134.Rampura upazilas/thanas of Dhaka district from Dhaka division it will be as like as 010135.Sutrapur upazilas/thanas of Dhaka district from Dhaka division it will be as like as 010136.Shah Ali upazilas/thanas of Dhaka district from Dhaka division it will be as like as 010137. Shahbagh upazilas/thanas of Dhaka district from Dhaka division it will be as like as 010138. Sher-e-Bangla Nagor upazilas/thanas of Dhaka district from Dhaka division it will be as like as 010139. Shyampur upazilas/thanas of Dhaka district from Dhaka division it will be as like as 010140. Sabujbagh upazilas/thanas of Dhaka district from Dhaka division it will be as like as 010141.Tejgaon upazilas/thanas of Dhaka district from Dhaka division it will be as like as 010142.Tejgaon Industrial Area upazilas/thanas of Dhaka district from Dhaka division it will be as like as 010143.Turag upazilas/thanas of Dhaka district from Dhaka division it will be as like as 010144.Uttar Khan upazilas/thanas of Dhaka district from Dhaka division it will be as like as 010145.Uttara upazilas/thanas of Dhaka district from Dhaka division it will be as like as 010146. For example, a citizen was birth in the year of 1960 in Dhaka division at Dhaka district from Tejgaon Industrial Area upazilas/thanas then his/her unique NID number will be in this stage 1960010143.

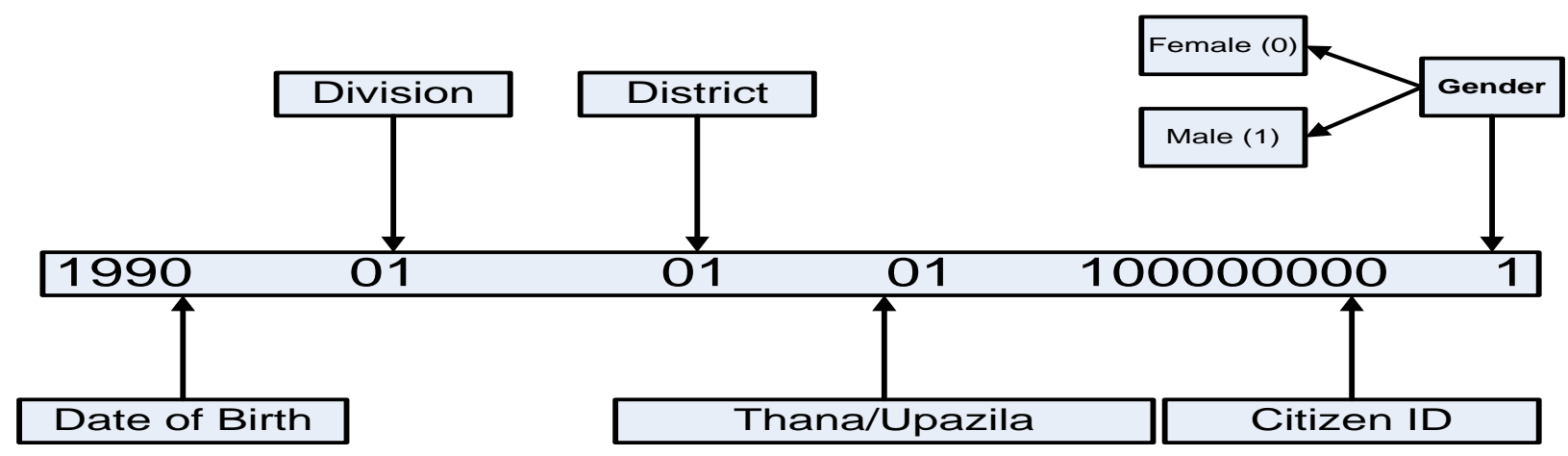

Figure 12: Code allocation for a citizen in UNID

From the figure 11 it was shown that a citizen was birth in the year of 1960 in Dhaka division at Dhaka district from Mirpur upazilas/thanas then his/her unique NID number will be in this stage 1960010128.A sample UNID number and its functions were presented here as an example in the figure 12. This is the sample format of proposed universal NID (UNID) number 19900101011000000001.In this format the date of birth 1990 that means it will be continued till in the year of 9999. The research allocates two digits for division in this system Bangladesh can be divided into 99 divisions. There were two digits for district that means in each division there were 99 districts. In this system Bangladesh can included 9801 districts. If in future Bangladesh wants to divide its districts in to 9801 till this system will be appropriated. In the next step two digits for thana or upazila in this system at best 99 thana or upazila can be included in each district. In this systems Bangladesh can divide its upazila or thana in 9 lakhs 70 thousand 2 hundred 99 in number $(9801 * 99=970299)$. In citizen ID portion 9 digits were allocated in this system at best 99 , 99, 99, 999 citizens will be allocated in each division. If in the near future 99 divisions, the total population $98,999,999,901$ can be counted in this system. The last part of this system a unique ID for male (1) and female (0) will be allocated. From the figure 11 it was shown that all the above data. 


\section{Recommendations}

There are some critical recommendations regarding the UNID of Bangladesh for the future consideration which were presented here

1) To make a link to national database and universal NID as a result all the data can be verify by the proper authority.

2) All the child those who born in Bangladesh must be registered in each birth register office and this birth register office will be linked to the national data center of national database office.

3) Union Information Center must be updated and some skilled people should be appointed for providing all kinds of online or ICT services for the mass people.

4) In all kinds of applications for example to admit into hospital, to get any certificate, to get admitted into school, college, university or any other institutions there must submit the Universal NID number to the respective office and this office transfer all the data to the related ministry or national data center or national database office.

5) To update the voters, national data center or national database office published a updated list those who touch at 18 in their age.

6) To calculate the population of Bangladesh this Universal NID should be used because this UNID can calculate the population every minute and also find out the proportion of male and female, child, adult people, educated, uneducated, married, unmarried, employed and unemployed etc.

7) This Universal NID can be linked to the department of passport and immigration as a result the information of a citizen of Bangladesh can easily verified in a shortest possible time within a minimum cost.

8) All the private and public service institutes (such as hospitals, banks, private offices, insurance companies etc.) should be recorded all services which they were provided to the citizen as a result the transparency of the government will be maintained and a good egovernment will be established.

9) Government and nongovernment educational institutes such as primary schools, high schools, colleges and universities used the Universal NID for the initial documents as a result every year how much students get admitted into and how many passed in primary, secondary, higher secondary, graduate and post-graduation can be find out easily.

10) Government can easily monitor all the government organizations with proper budgeting if all the departments and ministries will be connected national data center or national database office.

11) The GDP, GNP, Per Capita Income, Economic development, employment rate, unemployment rate etc. can be calculated easily within a short possible time.

12) Government can maintain a proper and fruitful budget for every fiscal year by using the data of national data center or national database office.

13) To maintain the Law and Order situation, an UNID can help to maintain the smooth operation through the country. If any crime can have occurred by culprit which can easily identified by the law enforcing agency and take an action within a very short possible time.

14) A Universal NID (UNID) card can prevent illegal immigration in Bangladesh. The Border Guard Bangladesh (BGB) may tract the citizen of Bangladesh.

15) We can give the proper quota in various jobs for the underprivileged and minority people in Bangladesh by using the Universal NID(UNID). The verification of quota will be easy 
and quick by using the UNID quota system. For an example in Pakistan, the NID cards are used to enforce a quota system.

16) The UNID can be used as a social engineering tools. China are using the NID as a tool of social engineering. In our country we can use the UNID for social engineering tools.

17) The UNID can be powerful tool against crime and easily prevent the criminal activities in Bangladesh. In UK ID were used as a main tool of crime prevention. As the same way we can use the UNID as a tool for identifying the crimes and criminals.

18) The UNID will be also a helpful and strong support to collect Tax from all sources. The Tax authority can identify the number of tax payees in every year. If any one of them can give their tax on time the authority can take any action against them. For example, in Australia, the purpose of the proposed card was to fight tax evasion.

19) The UNID will be a social welfare entitlement. By using the UNID the ministry of social welfare can identify the vulnerable people in remote areas. In New Zealand NID were used for establishing Social Welfare entitlement.

20) The UNID can also help the government to improve government administrative efficiency and to play a key role in dismantling border controls. Such as in Spain, Portugal, Thailand and Singapore, ID cards have been linked to national registration systems, which in turn form the basis of government administration.

\section{Conclusion}

The UNID card in Bangladesh can be the key elements to make the dream comes true as digital Bangladesh. This UNID can be a single card for all purposes inside and outside of this country. There will be some barriers to implement this UNID card systems in full phase. To maintain the security of the data of individual citizen will be a big challenge. Though the government has made a good initiative to make smart NID card for their nation in compare other than developed countries. If the Bangladesh can make a proper digital UNID card it will be a historical sign for the rest of the developing and under developing countries of the world. The scope of the future research to maintain the security challenges of UNID card in Bangladesh.

\section{Acknowledgements}

The author wish to express a special thanks to the all government stakeholders those who help me to collect data from various important note of digital Bangladesh. The authors also want to give a special think to all the senior professors from BIBM and Leading University those who gave the immense support for conducting a successful research, without their cordial support it was quite impossible to complete.

People who contributed to the work but do not fit criteria for authorship should be listed in the Acknowledgments, along with their contributions. It is advised that authors ensure that anyone named in the acknowledgments agrees to being so named. Funding sources that have supported the work should also be cited.

\section{References}

[1] Ailsa, K., \& Liz, L.-K. (2008). Citizens' attitudes towards e-government and e-governance: a UK study. International Journal Of Public Sector Management, 21(7), 723-738. 
[2] ALONSO, Á. I. (2009). E-PARTICIPATION AND LOCAL GOVERNANCE: A CASE STUDY. Theoretical and Empirical Researches in Urban Management(3(12)), 49-60.

[3] Bangladesh. (2016, October 2). Retrieved October 26, 2017, from www.dhakatribune.com: http://www.dhakatribune.com/bangladesh/2016/10/02/19424/

[4] Bangladesh National. (2016, October). Retrieved Octeber 26, 2017, from www.dhakatribune.com: http://www.dhakatribune.com/bangladesh/2016/10/02/19424/

[5] Betterthancash. (2015, June 2). Retrieved August 26, 2017, from www.betterthancash.org: https://www.betterthancash.org/news/media-releases/making-digital-bangladesh-vision-2021-areality-government-joins-the-better-than-cash-alliance

[6] Bhuiyan, S. M. (2011). Moderninzing BangladeshPublic Administration through egovernance:Benefits and Challenges. Government Information Quarterly, 54-65.

[7] Bovaird , T., \& Löffler, E. (2002). Moving from excellence models of local service delivery to benchmarking 'good local governance'. International Review of Administrative Sciences, 9-15.

[8] Chul , D., \& Eom, T. H. (2009). Anticorruption effects of information communication and technology (ICT) and social capital. International Review of Administrative Sciences, 100-110.

[9] Digital Bangladesh. (2013, February 12). Retrieved August 26, 2017, from e-sheba: http://a2i.pmo.gov.bd/wp-content/uploads/2016/06/Digital-Bangladesh.pdf

[10] Digital India. (2017, February 12). Retrieved July 23, 2017, from Digital India: http://www.cmai.asia/digitalindia/article.php

[11] Digital India Progress. (2017, May 23). Retrieved July 17, 2017, from Digital India: http://www.cmai.asia/digitalindia/digitalindiaweek.php

[12] Digital India/Pillars. (2017, June 24). Retrieved July 24, 2017, from Digital India: http://www.cmai.asia/digitalindia/

[13] Digital world 2017. (2017, May 24). Retrieved October 26, 2017, from https://www.digitalworld.org.bd/: https://digitalworld.org.bd/main/pages/mobile-innovation-expogaming-expo

[14] Dong, C. S., \& Tae, H. ,. (2008). E-Government and Anti-Corruption: Empirical Analysis of International Data. Intl Journal of Public Administration(31), 298-316.

[15] Gupta, A. (2017, May 12). Digital India. Retrieved July 23, 2017, from Digital India: http://www.cmai.asia/digitalindia/pdf/DigitalIndia.pdf

[16] Haricharan, R., \& Ponnurangam, K. (2010). The Unique Identification Number Project: Challenges and Recommendations. ICEB 2010 (pp. 146-153). LNCS 6005: Springer-Verlag Berlin Heidelberg.

[17] Heeks, R. (2006). Implementing and Managing eGovernment. The Electronic Journal on Information Systems in Developing Countries, 1-12.

[18] Islam, M. (2008, October). Towards a sustainable e-participation implementation model. European Journal of ePractice, 1-7.

[19] Learninall. (2016, June 24). Retrieved February 12, 2017, from www.Learingall.com: www.learningall.com

[20] M, A., \& S, D. (2010). Implementation of e-Government: Advantages and Challenges. Griffith Research Online (pp. 79-86). Griffith University.

[21] Macintosh, A., \& Whyte, A. (2006). EVALUATING HOW EPARTICIPATION CHANGES LOCAL DEMOCRACY. eGovernment Workshop '06 (eGOV06) (pp. 1-6). West London: Brunel University, West London, UB8 3PH.

[22] Macintosh, P. A. (2004). Characterizing E-Participation in Policy-Making. 37th Hawaii International Conference on System Sciences (pp. 1-10). Hawaii: 37th Hawaii International Conference on System Sciences.

[23] Mona, R., Samuel, B., \& Mats, D. (2010). Public Decision Making Support: A Developing Country Perspective. IST-Africa 2010 Conference Proceeding (pp. 1-6). IIMC International Information Management Corporation, 2010.

[24] National. (2016, October 1). Retrieved October 26, 2017, from www.clickittefaq.com: 
http://www.clickittefaq.com/smart-nids-distribution-begins-on-sunday/

[25] Ndou, V. (. (2004). The Electronic Journal on Information Systems in Developing Countries, 18(1).

[26] Nkwe, N. (2012, September). E-Government: Challenges and Opportunities in Botswana. International Journal of Humanities and Social Science, 2(17), 39-44.

[27] Palvia, S. C., \& Sharma, S. S. (2016). E-government and e-governence:Dafination/Domain framework and Status around the world. India: Computer Society of India.

[28] PERSPECTIVE PLAN OF BANGLADESH 2010-2021. Dhaka,BD: General Economics Division and Planning Commission, Government of the People's Republic of Bangladesh .

[29] Rahman, L. (2015, March 23). 24TH ANNIVERSARY OF THE DAILY STAR (PART 1). Retrieved August 26, 2017, from thedailystar.net: http://www.thedailystar.net/supplements/24thanniversary-the-daily-star-part-1/digital-bangladesh-dreams-and-reality-73118

[30] Rahman, Z. (2016, October 30). Digital asia hub. Retrieved October 26, 2017, from www.digitalasiahub.org: https://www.digitalasiahub.org/2016/10/30/bangladesh-introduces-smart-national-identity-cards/

[31] Rao, P. T. (2004, December). ICT and e-Governance for Rural Development. Institute of Rural Management, Anand, Gujarat, 1-13.

[32] Rokonuzzaman, H. Z. (2016). ACHIEVING DIGITAL BY 2021 AND BEYOND. Dhaka,BD: Government of Bangladesh.

[33] ROSE, R. (2005). A Global Diffusion Model of e-Governance. Journal of Public Policy, 25(1), 527.

[34] Salim, I. (2017, September 26). http://www.dhakatribune.com/author/bss/. Retrieved October 26, 2017 , from http://www.dhakatribune.com/author/bss/: http://www.dhakatribune.com/bangladesh/2017/09/26/sheikh-hasina-digital-us/

[35] Simon, F., David, R., \& Fabrizio, R. (2007, December 4). e-Participation and Decision Analysis. DecisionAnalysis, 4(4), 221-226.

[36] Sujana, A., \& Ray, C. (2013). FACTORS AFFECTING CONSUMERS' CONTINUED USE OF INTERNET BANKING: EMPIRICAL EVIDENCE FROM AUSTRALIA. Australasian Journal of Information Systems, 18(1), 5-18.

[37] Tania, G., Devindra, R., \& John, W. (2007). Introducing a New E-Governance Framework in the Commonwealth: From Theory to Practic. THE ASIA PACIFIC JOURNAL OF PUBLIC ADMINISTRATION, 29(2), 131-151.

[38] Vision 2012. (2015). Retrieved August 26, 2017, from wikipedia: https://en.wikipedia.org/wiki/Vision_2021

\footnotetext{
*Corresponding author.

E-mail address: mahbobdumis@gmail.com
} 